\title{
Direct Osmotic Desalination Technique by Solar Energy
}

\author{
Atabek Yuldashev, Ilnur Garipov, Renat Khaydarov* \\ Laboratory of Interdisciplinary Technologies, Institute of Nuclear Physics, Tashkent, Uzbekistan \\ Email address: \\ renat2@gmail.com (R. Khaydarov) \\ ${ }^{*}$ Corresponding author
}

\section{To cite this article:}

Atabek Yuldashev, Ilnur Garipov, Renat Khaydarov. Direct Osmotic Desalination Technique by Solar Energy. International Journal of Natural Resource Ecology and Management. Vol. 5, No. 3, 2020, pp. 84-89. doi: 10.11648/j.ijnrem.20200503.11

Received: July 20, 2020; Accepted: July 30, 2020; Published: August 5, 2020

\begin{abstract}
Over the last decade direct (forward) osmosis has attracted much attention in practical applications including artesian water desalination, green power generation, industrial water purification etc. In comparison with the traditional reverse osmosis process the separation is due to natural osmosis, providing lower energy cost for external pressure that is needed for reverse osmosis and lower membrane fouling potential. The main problem for the direct osmosis application efficiency is a selection of appropriate draw solute (otherwise known as a working substance). In the present paper diethyl ether $\left(\mathrm{C}_{2} \mathrm{H}_{5}\right)_{2} \mathrm{O}$ has been considered as a working substance having a relatively high osmotic pressure. Heating regeneration has been explored to obtain fresh water and recover the proposed draw solution. The advantage of the diethyl ether over known draw solutes has been discussed. It was noted that for further commercial applications of the diethyl ether as a working substance the membrane should have better characteristics of water permeability, stability, selectivity, and mechanical strength. The pilot device based on the described direct (forward) osmosis technique with the productivity of $1 \mathrm{~m}^{3} / \mathrm{hr}$ has been manufactured. In the beginning of 2020 the pilot device was successfully installed in a village of Navoiy Region, Uzbekistan to provide its inhabitants with the clean water.
\end{abstract}

Keywords: Forward Osmosis, Draw Solution, Osmotic Pressure, Power Generation, Wastewater Treatment

\section{Introduction}

Desalination is a separation process that produces two streams: fresh water and saline solution (brine). Saline water is classified as brackish water when the salt concentration, mostly sodium chloride, is between $1,000 \mathrm{ppm}$ and 10,000 ppm; hard brackish water when salinity is between 10,000 ppm and 35,000; and seawater when the salinity exceeds $35,000 \mathrm{ppm}$ [1]. Two main commercial desalination technologies have gained acceptable recognition throughout the world, namely those based on thermal or on membrane processes. Membrane processes include Reverse Osmosis (RO) and Electrodialysis (ED). Whereas ED is more suitable for brackish water, RO can be used for both brackish water and seawater. Thermal processes, due to their high-energy requirements, are normally used for seawater desalination.

The energy consumption in desalination processes is as follows: in thermal plants (Multi-Stage Flash - MSF and Multi-Effect Distillation - MED) if not connected to power plants, $290 \mathrm{MJ} / \mathrm{m}^{3}$ is required, and $160 \mathrm{MJ} / \mathrm{m}^{3}$ when connected to power plants. The electrical consumption in these plants is 3.6 and $2.3 \mathrm{kWh} / \mathrm{m}^{3}$ in MSF and MED, respectively. In RO plants and for seawater, electrical consumption is about $10 \mathrm{kWh} / \mathrm{m}^{3}$ without energy recovery, $2-5 \mathrm{kWh} / \mathrm{m}^{3}$ with energy recovery depending on the type of energy recovery system used. For small plants, the power consumption may exceed $15 \mathrm{kWh} / \mathrm{m}^{3}$. In case of brackish water desalination, the power requirement is $1-3 \mathrm{kWh} / \mathrm{m}^{3}$ for $\mathrm{RO}$. As for $\mathrm{ED}$, the electrical consumption can vary in the range of $0.5-10 \mathrm{kWh} / \mathrm{m}^{3}$ depending on water salinity. For example, it would be assuming product salinity of $500 \mathrm{ppm}$, 1.5 and $4 \mathrm{kWh} / \mathrm{m}^{3}$ for feed water salinity of 1,500 and 3500 ppm, respectively. For Vapor Compression (VC) Distillation, the requirement is $8.5-16 \mathrm{kWh} / \mathrm{m}^{3}$ depending on the plant size [1-6]. Energy consumption of solar thermal desalination process (solar collectors and solar ponds) is about 2,500 $\mathrm{MJ} / \mathrm{m}^{3}$ without energy recovery and $250-500 \mathrm{MJ} / \mathrm{m}^{3}$ with energy recovery [7]. 
Unfortunately these methods are still not prevalent in developing countries including Uzbekistan due to high power consumption and/or material cost (MSF, MED, RO), low productivity (solar thermal desalination), low efficiency of desalination of water with high concentration of salts (ED), requirements in periodical supplying chemicals (ion exchange method). Moreover communities of remote villages in developing countries often do not have access to electricity during the whole day and relies on costly and limited supplies of diesel fuel for their energy needs. Therefore, for such regions it is very important to find new low-energy consuming techniques of water desalination.

The purpose of this work was to develop new low-energy consuming water desalination method based on direct osmosis process that can effectively use solar cells as an energy source for pumping various fluids (feed, brine, product, working solution) and solar energy/ambient temperature/waste heat/geothermal energy for recovery of working solution.

\section{Principle of the Method}

To describe the developed water desalination method based on direct osmosis process let us suppose that (see Figure 1) there is a salted water (the feed) containing contaminants with molar concentration of dissociated ions $\mathrm{C}_{\mathrm{a}}$ in section $\mathrm{A}$. In section $\mathrm{B}$ there is a water solution of a certain substance with initial molar concentration $\mathrm{C}_{\mathrm{bi}}$. Let us call them as a working fluid (WF) with a working substance (WS), respectively. Sections A and B are divided from each other by a semipermeable membrane which is permeable for water molecules and impermeable for substances dissolved in section $\mathrm{A}$ and for the working substance. Let us also suppose that the condition $\mathrm{C}_{\mathrm{a}}<<\mathrm{C}_{\mathrm{bi}}$ is met. Then in order to equilibrate the difference in chemical potential, osmosis movement starts, i.e. water begins to diffuse through the membrane from section A to section B. In other words in section B WF is diluted by clean water pulled out from section A. Water solution of WS with final molar concentration $\mathrm{C}_{\mathrm{bf}}$ from section $\mathrm{B}$ is transported to section $\mathrm{C}$ where water and WS are separated or water is removed from a part of diluted WF.

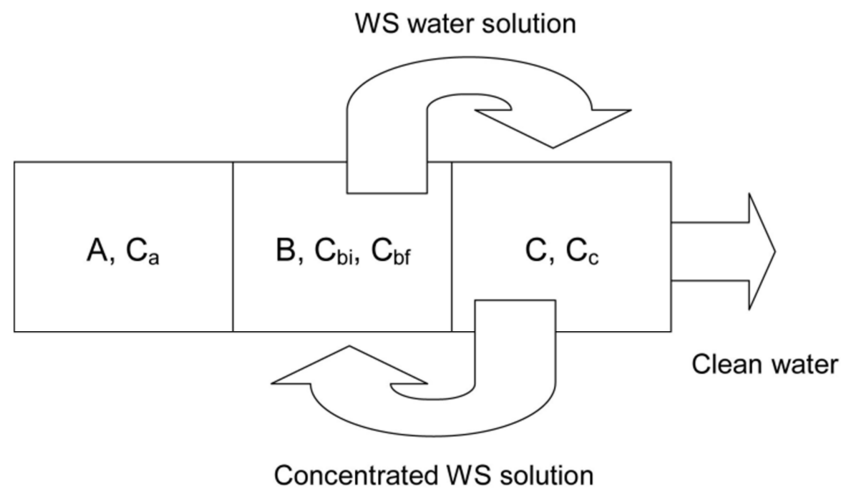

Figure 1. Principle of operation of direct osmosis desalination method.

Let us suppose that $\Delta \mathrm{H}_{1}$ is the enthalpy of dilution of WF by the clean water passed through semipermeable membrane from section A to section B. Energy that is necessary to separate WS and clean water in section $\mathrm{C}$ is determined by enthalpy $\Delta \mathrm{H}_{2}$. It is clear that $\left|\Delta \mathrm{H}_{2}\right|$ is less than $\left|\Delta \mathrm{H}_{4}\right|$, where $\Delta \mathrm{H}_{4}$ - is the enthalpy of the reverse osmosis (RO) process of removing salt ions from the feed. In proposed direct osmosis desalination technique solar thermal energy or any other source of heat (ambient temperature/geothermal energy/waste heat) can be effectively used for the separation of clean water and WS. Therefore total electrical energy consumption will be much less that in case of RO technique. Moreover, as the coefficient of efficiency of solar cells usually is less than $20 \%$ the total solar energy consumption in the proposed method can be less than that in the RO technique. The enthalpy diagram of desalination process is given in Figure 2.

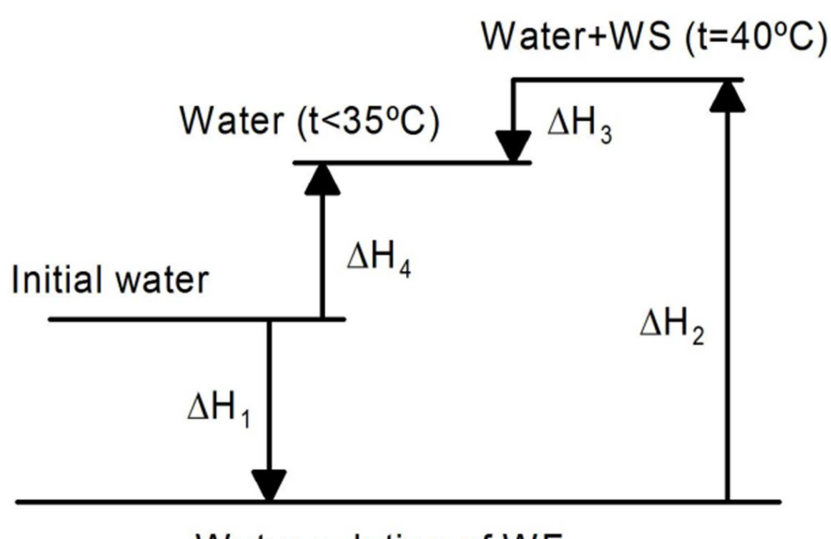

Water solution of WF

Figure 2. Enthalpy diagram of desalination process.

The process of water transition from section A to section B can be described by the following equations:

$$
\begin{aligned}
& \mathrm{Q}=\mathrm{AS} \mathrm{K} \mathrm{K}_{\mathrm{t}} \mathrm{K}_{\mathrm{f}}\left(\mathrm{P}_{\mathrm{a}}+\mathrm{K}^{\mathrm{r}} \Delta \pi-\mathrm{P}_{\mathrm{b}}\right) \\
& \Delta \pi=\pi_{\mathrm{bc}}-\pi_{\mathrm{ac}} \\
& \pi_{\mathrm{ac}}=\pi_{\mathrm{a}}\left(\mathrm{C}_{\mathrm{ac}} / \mathrm{C}_{\mathrm{a}}\right) \mathrm{p}_{\mathrm{fA}} \\
& \pi_{\mathrm{bc}}=\pi_{\mathrm{b}}\left(\mathrm{C}_{\mathrm{bc}} / \mathrm{C}_{\mathrm{bi}}\right) \mathrm{p}_{\mathrm{fB}}
\end{aligned}
$$

where $\mathrm{Q}$ is the permeate flow, $\mathrm{A}$ is the water permeability coefficient of the membrane, $\mathrm{S}$ is the membrane surface area, $\mathrm{K}_{\mathrm{t}}$ is the temperature correction factor, $\mathrm{K}_{\mathrm{f}}$ is the fouling factor, $\mathrm{K}_{\mathrm{r}}$ is the reflection coefficient measuring selectivity of the membrane, $\mathrm{P}_{\mathrm{a}}$ is the pressure in section $\mathrm{A}, \mathrm{P}_{\mathrm{b}}$ is the pressure in section $\mathrm{B}, \pi_{\mathrm{ac}}$ and $\pi_{\mathrm{bc}}$ are the average concentrate osmotic pressures in sections $\mathrm{A}$ and $\mathrm{B}$, respectively, $\pi_{\mathrm{a}}$ and $\pi_{\mathrm{b}}$ are the osmotic pressures of feed and WS water solution, respectively, $\mathrm{C}_{\mathrm{ac}}$ is the concentration of the salt concentrate on the membrane surface in section $\mathrm{A}, \mathrm{C}_{\mathrm{bc}}$ is the concentration of WS concentrate on the membrane surface in section $\mathrm{B}, \mathrm{p}_{\mathrm{fA}}$ and $\mathrm{p}_{\mathrm{fB}}$ are the concentration polarization coefficients. Many parameters in equations (1) - (4) depend on specifications of the membrane and direct osmosis equipment features including direction of feed water and WF fluxes in the membrane, their flow rates, as well as type, thickness, 
tortuosity and porosity of the membrane and its support layer, etc. Exact value of Q can be determined experimentally.

Specific energy consumption of water desalination process $\Delta \mathrm{E} / \Delta \mathrm{m}_{\mathrm{w}}$ in section $\mathrm{C}$ can be estimated by the equation (5):

$$
\Delta \mathrm{E} / \Delta \mathrm{m}_{\mathrm{w}}=\left(\mathrm{c}_{\mathrm{bf}} \Delta \mathrm{t}^{\circ}+\lambda_{\mathrm{ws}} \mathrm{C}_{\mathrm{bf}}\right) /\left(1-\mathrm{C}_{\mathrm{bf}}\right)
$$

where $m_{w}$ is the mass of desalinated water, $c_{b f}$ is the specific heat of water solution of WS with final molar concentration $\mathrm{C}_{\mathrm{bf}}, \Delta \mathrm{t}^{\circ}$ is the difference between ambient temperature and WS boiling-point, $\lambda_{w s}$ is the specific heat of evaporation of WS in the solution with final molar concentration $C_{b f}$. If the WS boiling-point is low then $\mathrm{c}_{\mathrm{bf}} \Delta \mathrm{t}^{\circ}$ from equation (5) can be consumed for example from a small solar heater. In this case the electric heating unit is used only for WS evaporation. If WS has a small value of $\lambda_{\text {ws }}$ the electric energy consumption of the process of WS separation from clean water will be low.

The main problem of the proposed water treatment method is selection of WS. The selection of an appropriate WS is crucial for the direct osmosis process efficiency. The ideal WS should have low toxicity and low cost as some of its characteristics. Over the last decade various researches have been conducted for creating suitable WS for desalination processes. There are different types of WS that are categorized into organic-based WS, inorganic-based WS, and other compounds including emerging draw solutions such as magnetic nanoparticles (MNPs) and RO brines. These classifications can be sub-classified into ionic (electrolyte) and non-ionic (non-electrolyte) solutions based on whether the solution is made up of charged ions or if it is completely neutrally charged solutes [8]. We suggest the simplest and the most accessible methods of separation of water from working substance in section $\mathrm{C}$ are evaporation, freezing and forming crystalline hydrates. Definitely other methods of separation can be used as well. Some materials that might be utilized as WS are given in Table 1.

Table 1. Examples of materials can be used as a working substance.

\begin{tabular}{|c|c|c|c|}
\hline Type of working substance & Name of working substance & $\begin{array}{l}\text { Specifications ( } t_{b p}-\text { boiling point; } t_{f}-\text { fusing } \\
\text { point) }\end{array}$ & WS separation technique \\
\hline \multirow{2}{*}{ Alcohol } & Ethanol & $\mathrm{t}_{\mathrm{bp}}=78,39^{\circ} \mathrm{C}$ & WS evaporation \\
\hline & Glycerin & $\mathrm{t}_{\mathrm{f}}=20^{\circ} \mathrm{C}$ & WS freezing \\
\hline Ethers & Diethyl ether & $\mathrm{t}_{\mathrm{bp}}=35,6^{\circ} \mathrm{C}$ & water freezing or WS evaporation \\
\hline \multirow{4}{*}{ Amines } & Ethylamine & $t_{b p}=16,6^{\circ} \mathrm{C}$ & WS evaporation \\
\hline & Trimethylamine & $\mathrm{t}_{\mathrm{bp}}=3,5^{\circ} \mathrm{C}$ & WS evaporation \\
\hline & Diethylamine & $\mathrm{t}_{\mathrm{bp}}=56,3^{\circ} \mathrm{C}$ & WS evaporation \\
\hline & Methylamine & $t_{b p}=-6,5^{\circ} \mathrm{C}$ & WS evaporation \\
\hline Ketones & Acetone & $\mathrm{t}_{\mathrm{bp}}=56,24^{\circ} \mathrm{C}$ & WS evaporation \\
\hline
\end{tabular}

\section{Materials and Equipment}

\subsection{Working Substance and Osmosis Membrane}

In our experiments we used diethyl ether $\left(\mathrm{C}_{2} \mathrm{H}_{5}\right)_{2} \mathrm{O}$ as the working substance and RE-1812-LP reverse osmotic membrane produced by SAEHAN Inc (South Korea) as the semipermeable membrane for direct osmosis process. These Thin Film Composite (TFC) polyamide membranes (PA) consist of a porous support layer and a thin film dense layer which is a cross linked membrane skin and is formed in situ on the porous support layer made of polysulfone. The thin film dense layer is a crosslinked aromatic polyamide made from interfacial polymerization reaction of a polyfunctional amine such as m-phenylenediamine with a polyfunctional acid chloride such as trimesoyl chloride.

\subsection{Direct Osmosis Laboratory Set-up}

The laboratory experimental water desalination device was constructed as shown in Figure 3. Vessel 1 with 80 liters of $\mathrm{NaCl}$ solution was allocated at height of $0.5 \mathrm{~m}$ to exert a hydrostatic feed pressure of $5 \mathrm{kPa}$ on a semi-permeable membrane 2. The flow rate was regulated by valve 10 discharging concentrated water. On the other side of the membrane 2 there was a working liquid: water solution of diethyl ether $\left(\mathrm{C}_{2} \mathrm{H}_{5}\right)_{2} \mathrm{O}$ boiling point of which is $35,6^{\circ} \mathrm{C}$ and water solubility of $100 \mathrm{ml} / 1$ at $16^{\circ} \mathrm{C}$.

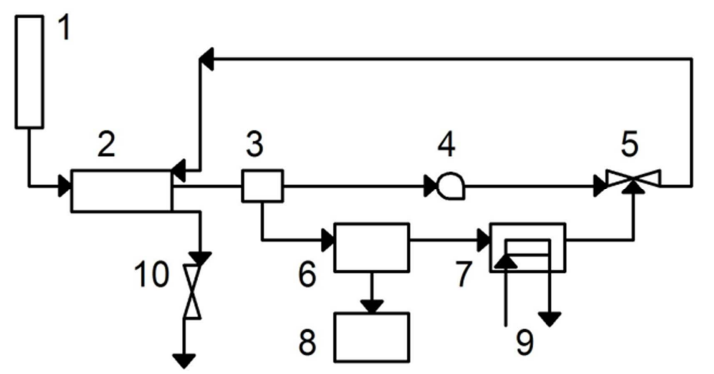

Figure 3. Scheme of the device: 1 - Vessel with $\mathrm{NaCl}$ water solution, 2 semipermeable membrane, 3 - flow dividing valve, 4 - pump, 5 - ejector, 6 extending box with heater, 7-condenser, 8 - collector, 9 - cooling water, 10 flow rate regulated valve.

The permeate, i.e. the working liquid with clean water pulled out through the membrane 2, was divided into two parts with flow dividing valve 3 . Then the most part of the permeate came back to the semi-permeable membrane 2 by pump 4 . The smaller part of permeate went in extending box 6 with an electrical heater (in the laboratory experimental device) holding the temperature at $38-40^{\circ} \mathrm{C}$. As a result, clean water was accumulated in the collector 8 and vapor of diethyl ether went into condenser 7 cooled by water 9 . Condensed diethyl ether was pulled in the flow of WF by the ejector 5 
reconcentrating the diethyl ether water solution for the reuse in the semi-permeable membrane 2.

\section{3. $\mathrm{Na}, \mathrm{Cl}$ and $\left(\mathrm{C}_{2} \mathrm{H}_{5}\right)_{2} \mathrm{O}$ Concentrations Measurements}

Deionized water was used to prepare the sodium chloride and diethyl ether solutions. Concentrations of $\mathrm{Na}$ and $\mathrm{Cl}$ were determined by neutron activation analysis [9]. Water samples were irradiated at the nuclear reactor of the Institute of Nuclear Physics, Tashkent, Uzbekistan. Ge(Li) detector with a resolution of about $1.9 \mathrm{keV}$ at $1.33 \mathrm{MeV}$ and a 6144-channel multichannel analyzer were used. The area under $\gamma$-peaks of radionuclides ${ }^{24} \mathrm{Na}$ (half-life is $15 \mathrm{~h}$, energy of the $\gamma$-peaks are $1.368 \mathrm{MeV}$ and $2.754 \mathrm{MeV}$ ) and ${ }^{38} \mathrm{Cl}$ (half-life is $37.7 \mathrm{~min}$, energy of the $\gamma$-peaks are $1.642 \mathrm{MeV}$ and $2.167 \mathrm{MeV}$ ) were measured to calculate the concentrations of $\mathrm{Na}$ and $\mathrm{Cl}$ respectively. Concentration of $\left(\mathrm{C}_{2} \mathrm{H}_{5}\right)_{2} \mathrm{O}$ in water was determined by gas chromatograph "Svet-5" (Russia) using standard methods [10].

\subsection{WF and WS}

Flow rates of feed water and WF in the device were measured by Flow Meter "Zenner" (Germany) over a selected time period. Direct osmosis tests were conducted using the working liquid and the feed maintained at the same temperature $24 \pm 1,5^{\circ} \mathrm{C}$. Energy $E_{h}$ of water heating from $t_{i}=$ $24^{\circ} \mathrm{C}$ to $t_{f}=40^{\circ} \mathrm{C}$ and energy $E_{s}$ of separation of WS from clean water were calculated as follows: $E_{h}=c_{w}\left(t_{f}-t_{i}\right)$ and $E_{s}$ $=\lambda \mathrm{m}_{\mathrm{ws}}$, where $\mathrm{c}=4.2 \mathrm{~kJ} /(\mathrm{kgKK})$ is specific heat of WF with concentration of WS equal to $\mathrm{C}_{\mathrm{bf}}, \mathrm{m}_{\mathrm{w}}=25 \mathrm{~kg}$ is mass of $\mathrm{WF}$ going for separation of WS from clean water, $\lambda=384 \mathrm{~kJ} / \mathrm{kg}$ is specific heat of evaporation of diethyl ether, $\mathrm{m}_{\mathrm{ws}}$ is mass of diethyl ether in WF going for separation of WS from clean water. Power of heater $P_{r}$ that is necessary to obtain clean water output of $25 \mathrm{l} / \mathrm{h}$ was determined as $\mathrm{P}_{\mathrm{r}}=\mathrm{UI}$, where $\mathrm{U}$ is electric heater voltage, $\mathrm{V}$; I is the electric current of heater, A.

\subsection{The Pilot Device}

In a pilot device solar batteries of $12 \mathrm{~V}$ with a total capacity of $500 \mathrm{~W}$ provided by AQUASOL Ltd., Uzbekistan were used as an energy source and ion-exchange fiber sorbents developed in the Institute of Nuclear Physics of Academy of Sciences of Republic of Uzbekistan [11] were used to remove salts of hardness and ions of iron. The specific surface of the fiber sorbents is $(2-3) \cdot 10^{4} \mathrm{~m}^{2} / \mathrm{kg}$ and their exchange capacity is $3.5-4.0 \mathrm{meq} / \mathrm{g}$. In the pilot device a water disinfection device based on oligodynamic method developed in the Institute of Nuclear Physics was used to kill bacteria to prevent destruction of semi-permeable membrane and prevent water contamination in emergency situations [12]. The device provides killing all types of pathogens in water and has very low energy consumption of $0,1 \mathrm{~W}$-h for water flow rate of 1 $\mathrm{m}^{3}$ /hour. The above-mentioned pretreatment was necessary to prevent membrane fouling.

In the pilot device the vessel 1 with volume of 2001 was located at height of $3 \mathrm{~m}$ and filled by a water pump with power of $75 \mathrm{~W}$. The water pretreatment unit containing a water filter on the base of fiber sorbents and water disinfection device was installed between the vessel 1 and the semi-permeable membrane 2. The pump 4 and pump for cooling water 9 had power of $75 \mathrm{~W}$. Solar heater was used in the extending box 6 to heat water up to $38-40^{\circ} \mathrm{C}$.

\section{Results and Discussion}

Estimated value of osmotic pressure of our WF (water solution of $\left(\mathrm{C}_{2} \mathrm{H}_{5}\right)_{2} \mathrm{O}$ with concentration of $\left.100 \mathrm{ml} / \mathrm{l}\right)$ is 2.35 $\mathrm{MPa}$. Meanwhile for instance, $4 \mathrm{~g} / 1 \mathrm{NaCl}$ water solution with degree of dissociation of 0.44 has osmotic pressure of 0.39 $\mathrm{MPa}$. Thus the difference between the osmotic pressures was always large enough, i.e there was self-sustaining osmotic movement without necessity of usage energy-consuming pumps in contrast to reverse osmosis water treatment method.

Some test results of the laboratory experimental device are given in Table 2. Three samples with various water salinities were chosen for the tests: $1 \mathrm{~g} / 1$ corresponding to a regulation limit for drinking water salinity in Uzbekistan, $4 \mathrm{~g} / \mathrm{l}$ as a sample of water salinity in most regions of Uzbekistan and 20 $\mathrm{g} / \mathrm{l}$ as a sample of artesian water salinity in Navoiy Region, Uzbekistan. Mentioned in the Table $2 \mathrm{c}_{\mathrm{a}}, \mathrm{c}_{\mathrm{bi}}, \mathrm{c}_{\mathrm{bf}}$ and $\mathrm{c}_{\mathrm{c}}$ are mass concentrations corresponding to molar concentrations $\mathrm{C}_{\mathrm{a}}, \mathrm{C}_{\mathrm{bi}}$, $\mathrm{C}_{\mathrm{bf}}$ and $\mathrm{C}_{\mathrm{c}}$, respectively. The flow rate of WF should be low to minimize the pump power consumption. Two values of the WF flow rate were tested: equal to about two values of productivity of the device (a minimal allowable flow rate) and ten values of its productivity. In our experimental device the energy was consumed mainly at the stage of WS separation from the water (the heater with maximum power of $600 \mathrm{~W}$ ) and for WS circulation by the pump (power of $15 \mathrm{~W}$ ) to obtain clean water output of 25 liters per hour. The temperature of influent water was $24^{\circ} \mathrm{C}$. The comparison of calculated energy $\mathrm{E}_{\mathrm{h}}$ of water heating up to $40^{\circ} \mathrm{C}$ and energy $\mathrm{E}_{\mathrm{s}}$ of separation WS from the water shows that the main part of energy from 85 to $95 \%$ is consumed for water heating. The heater power of the device $\mathrm{P}_{\mathrm{r}}$ that is necessary to obtain clean water output of 25 $\mathrm{l} / \mathrm{h}$ is $500-600 \mathrm{~W}$ and practically does not depend on the initial concentrations of salts in the range from 1 to $20 \mathrm{~g} / \mathrm{l}$. This power decreases when temperature of influent water increases and approaches $35-40{ }^{\circ} \mathrm{C}$ because only $60-100 \mathrm{~W}$ is consumed for the separation of clean water from WS.

Total electric energy consumption of the desalination process can be essentially decreased by using a solar heater instead of the electric heater used in the laboratory experimental device. The pilot device with productivity of 1 $\mathrm{m}^{3} / \mathrm{hr}$ was installed in Navoiy Region, Uzbekistan. Total concentration of salts in initial water was about $17 \mathrm{~g} / \mathrm{l}$. Test results of the device are shown in Table 3. Due to replacing the electric heater 6 by the solar heater the total electric power of the device did not exceed $500 \mathrm{~W}$, i.e. it was much less than energy consumption of RO method. The product salinity after the treatment was about $50 \mathrm{mg} / \mathrm{l}$. 
Table 2. Test results of laboratory experimental model (clean water output is $25 \mathrm{l} / \mathrm{h}$, initial temperature of water is $24^{\circ} \mathrm{C}$ ).

\begin{tabular}{|c|c|c|c|c|c|c|c|c|c|}
\hline $\begin{array}{l}\mathrm{c}_{\mathrm{a}} \text { of } \mathrm{NaCl}, \\
\mathrm{g} / \mathrm{l}\end{array}$ & $\begin{array}{l}\text { Recovery (relation of } \\
\text { permeate and feed flow rates) }\end{array}$ & $\begin{array}{l}\text { Flow rate of } \\
W F, 1 / h\end{array}$ & $\begin{array}{l}\text { Part of WF for } \\
\text { water separa- tion }\end{array}$ & $\begin{array}{l}\mathrm{c}_{\mathrm{bi}}, \\
\mathrm{g} / \mathrm{l}\end{array}$ & $\begin{array}{l}\mathrm{c}_{\mathrm{bf}}, \\
\mathrm{g} / \mathrm{l}\end{array}$ & $\begin{array}{l}\mathbf{E}_{\mathrm{h}}, \\
\mathbf{k J}\end{array}$ & $\begin{array}{l}\mathbf{E}_{\mathrm{s}} \\
\mathbf{k J}\end{array}$ & $\begin{array}{l}\mathbf{P}_{\mathrm{r}} \\
\mathbf{W}\end{array}$ & $\begin{array}{l}\mathrm{c}_{\mathrm{c}} \text { of } \mathrm{NaCl}, \\
\mathrm{mg} / \mathrm{l}\end{array}$ \\
\hline \multirow{4}{*}{1} & \multirow{2}{*}{0.1} & 60 & 0.5 & 5 & 3.0 & 1600 & 29 & 500 & \multirow{4}{*}{$<10$} \\
\hline & & 300 & 0.1 & 5 & 4.6 & 1600 & 44 & 500 & \\
\hline & \multirow{2}{*}{0.5} & 60 & 0.5 & 7 & 4.1 & 1600 & 40 & 500 & \\
\hline & & 300 & 0.1 & 7 & 6.4 & 1600 & 62 & 500 & \\
\hline \multirow{4}{*}{4} & \multirow{2}{*}{0.1} & 60 & 0.5 & 20 & 12 & 1600 & 112 & 500 & \multirow{4}{*}{$<10$} \\
\hline & & 300 & 0.1 & 20 & 18 & 1600 & 176 & 550 & \\
\hline & \multirow{2}{*}{0.5} & 60 & 0.5 & 25 & 15 & 1600 & 140 & 500 & \\
\hline & & 300 & 0.1 & 25 & 23 & 1600 & 220 & 550 & \\
\hline \multirow{4}{*}{20} & \multirow{2}{*}{0.1} & 60 & 0.5 & 40 & 33 & 1600 & 224 & 600 & \multirow{4}{*}{$<20$} \\
\hline & & 300 & 0.1 & 40 & 37 & 1600 & 352 & 600 & \\
\hline & \multirow[b]{2}{*}{0.4} & 60 & 0.5 & 60 & 35 & 1600 & 336 & 600 & \\
\hline & & 300 & 0.1 & 60 & 55 & 1600 & 528 & 600 & \\
\hline
\end{tabular}

(where $c_{a}, c_{b i}, c_{b f}$ and $c_{c}$ are mass concentrations corresponding to molar concentrations $C_{a}, C_{b i}, C_{b f}$ and $C_{c}$, respectively; $E_{h}$ - energy of water heating from $t_{i}=24^{\circ} \mathrm{C}$ to $t_{f}=40^{\circ} \mathrm{C} ; \mathrm{E}_{\mathrm{s}}$ - energy of separation of WS from clean water; $\mathrm{P}_{\mathrm{r}}$ - Power of heater)

Our tests have shown following advantages of the proposed technique: a) the method does not require a high pressure pump to push water through the membrane; b) electric energy consumption of the method is very low $\left(0.5 \mathrm{kWh} / \mathrm{m}^{3}\right.$ in comparison with $2-5 \mathrm{kWh} / \mathrm{m}^{3}$ for RO and $2-4 \mathrm{kWh} / \mathrm{m}^{3}$ for MSF and MED) when solar energy or heat of ambient air are used to heat the water up to $36-40^{\circ} \mathrm{C}$; c) surface area of the solar heat exchanger of the device is $3-30$ times less than that of solar thermal desalination process because of lower solar energy consumption $\left(80 \mathrm{MJ} / \mathrm{m}^{3}\right.$ in comparison with 2,500 $\mathrm{MJ} / \mathrm{m}^{3}$ for solar thermal desalination process without energy recovery and $250-500 \mathrm{MJ} / \mathrm{m}^{3}$ with energy recovery); d) the method can be used for desalination of water with salt concentrations up to $40 \mathrm{~g} / \mathrm{l}$; e) since the disinfecting device is used in water pretreatment process the water keeps disinfecting properties for a long time (not less than 1 year) and water produced in hot time can be stored in water storage systems for cold seasons. Membrane scaling or fouling have been prevented by using ion exchange fiber water filters to remove salts of hardness and iron ions and water disinfection device to kill bacteria [13].

Table 3. Purification of water samples from Navoiy region, Uzbekistan.

\begin{tabular}{lll}
\hline Items & Influent water, $\mathbf{~ m g / l}$ & Effluent water, $\mathbf{~ g / / ~}$ \\
\hline $\mathrm{pH}\left(\right.$ at $\left.25^{\circ} \mathrm{C}\right)$ & 6.7 & 6.7 \\
$\mathrm{Ca}$ & 560 & 1.2 \\
$\mathrm{Mg}$ & 400 & 1.6 \\
$\mathrm{Cl}$ & 4590 & 7.1 \\
$\mathrm{NO}_{3}$ & 300 & $<0.02$ \\
$\mathrm{SO}_{4}$ & 3825 & 1.8 \\
$\mathrm{Na}$ & 3300 & 2.3 \\
$\mathrm{~K}$ & 1200 & 1.6 \\
\hline
\end{tabular}

The proposed application of diethyl ether as a WS for direct osmosis driven has the advantage over some known WS options described in scientific literature [14] due to its high osmotic pressure, low toxicity, easy recovery and low cost. A number of known WS including mono and divalent salts, electrolytes, sugars such as glucose and fructose, engineered nanoparticles, or fertilizers should be recovered by RO [15].
On the other hand the application of RO for WS recovery is technically feasible but economically and industrially unpractical $[14,15]$. The type of WS is more important than the osmotic pressure of draw solution, as osmotic pressure of draw solution does not play a significant role at higher osmotic pressure $[8,16]$.

The disadvantage of the proposed method with the diethyl ether as a WS is a short life time of the membrane material (not more than 2-3 months). We suppose that diethyl ether reacts with materials of membrane housing and agglutinative materials used in membrane assembling process. For using the diethyl ether as a WS the membrane should have higher characteristics of water permeability, stability, selectivity, and mechanical strength. Thus, there is an urgent need for the development of both WS and new types of membranes to overcome the difficulties in the moving from laboratory research to the practical applications.

\section{Conclusion}

Test results have shown the efficacy of water desalination device based on direct osmosis desalination technique. The devices utilizing solar batteries as an energy source can be used in remote regions for desalination of water with concentrations of salts up to $40 \mathrm{~g} / \mathrm{l}$. When solar energy or heat of ambient air are used to heat the working fluid up to $36-40^{\circ} \mathrm{C}$, the electric energy consumption of the method is very low: 0.5 $\mathrm{kWh} / \mathrm{m}^{3}$ in comparison with $2-5 \mathrm{kWh} / \mathrm{m}^{3}$ for RO and 2-4 $\mathrm{kWh} / \mathrm{m}^{3}$ for MSF and MED when solar energy or heat of ambient air are used to heat the water up to $36-40^{\circ} \mathrm{C}$. The surface area of the solar heat exchanger of the device is $3-30$ times less than for the solar thermal desalination process because of lower solar energy consumption $\left(80 \mathrm{MJ} / \mathrm{m}^{3}\right.$ in comparison with $2,500 \mathrm{MJ} / \mathrm{m}^{3}$ for solar thermal desalination process without energy recovery and $250-500 \mathrm{MJ} / \mathrm{m}^{3}$ with energy recovery). Desalinated water keeps disinfecting properties for a long time (not less than 1 year) and water produced in hot seasons can be stored in water storage systems for cold seasons. 


\section{References}

[1] J. Schippers, M. Kennedy, "5-Day Intensive Course on Membrane Technology in Drinking \& Industrial Water Treatment", Sponsored by Middle East Desalination Research Center, Muscat, Oman, January 2004.

[2] K. Wangnick, 2004 IDA Worldwide Desalting Plants Inventory. Report No. 18. Prepared and published by Wangnick Consulting. Wangnick Consulting $\mathrm{GmbH}$ Kuhstedtermoor, 19A, D-27442 Gnarrenburg, Germany.

[3] E. Tzen, R. Morris, Renewable energy sources for desalination, Solar Energy, 75, pp. 375-370 (2003).

[4] L. Garcia-Rodriguez, Renewable energy applications in desalination: state of the art, Solar Energy, 75, pp. 381-393 (2003).

[5] L. Garcia-Rodriguez, Seawater desalination driven by renewable energies: a review, Desalination, 143, pp. 103-113 (2002).

[6] L. Huanmin, J. C. Walton, and A. H. P. Swift, Desalination coupled with salinity gradient solar ponds, Desalination 136, pp. 13-23 (2001)

[7] Zarza, E., and Blanco, M., 1996, Advanced M. E. D. solar desalination plant: seven years of experience at the Plataforma Solar de Almería, in: Proceedings of the Mediterranean Conference on Renewable Energy Sources for Water Production, 10-12 June 1996, Santorini, Greece, pp. 45-49.

[8] N. Akther et al. Recent advancements in forward osmosis desalination: A review. Chemical Engineering Journal 281 (2015) 502-522.

[9] Alfassi, Z. B. 1990 Activation Analysis, Volumes I and II, CRC Press, Boca Raton, Florida.

[10] MUK4.1.655-96. Methodical instructions on gas chromatography determination of diethyl ether in water, Ministry of Health of Russian Federation.

[11] Khaydarov R. A., Gapurova O, Khaydarov R. R. and Cho S. Y, Fibroid Sorbents For Water Purification, Modern Tools and Methods of Water Treatment for Improving Living Standards, NATO Science Series, 1V Earth and Environmental Sciences Vol. 48, 2005, pp. 101-108.

[12] Khaydarov R. A., Khaydarov R. R., Olsen R. L. and Roger S. E., Use of electrolytically generated silver, copper and gold for water disinfection, Journal of Water Supply RT-Aqua, 53 (2004) pp. 567-572.

[13] Khaydarov R. A., Khaydarov R. R. Solar Powered Direct Osmosis Desalination // Desalination. -Elsevier, 2007. - vol. 217. pp. 225-232.

[14] Chung T.-S. et al. Forward osmosis processes: Yesterday, today and tomorrow. Desalination 287 (2012) 78-81.

[15] Coday B. D. et al. The sweet spot of forward osmosis: Treatment of produced water, drilling wastewater, and other complex and difficult liquid streams. Desalination 333 (2014) $23-35$.

[16] Liu Y., Mi B., Combined fouling of forward osmosis membranes: synergistic foulant interaction and direct observation of fouling layer formation. J. Membr. Sci. 407-408 (2012) 136-144. 